\title{
SILVER DIPHOSPHINE COMPLEXES \\ AS ANTIMITOCHONDRIAL AGENTS
}

\author{
Susan J. Berners-Price ${ }^{1}$, Doreen C. Collier ${ }^{2}$, Peter J. Sadler ${ }^{3}$, \\ Rodney E. Sue ${ }^{3}$ and David Wilkie ${ }^{2}$ \\ 1 Faculty of Science, Griffith University, Nathan, Queensland, Australia 4111 \\ 2 Department of Biology, University College, University of London, \\ Gower Street, London WC1E 6BT, UK \\ 3 Department of Chemistry, Birkbeck College, University of London, \\ 29 Gordon Square, London WC1H OPP, UK
}

Like their $\mathrm{Au}(\mathrm{I})$ counterparts, silver complexes of the type $\left[\mathrm{M}\left(\mathrm{R}_{2}^{\prime} \mathrm{P}\left(\mathrm{CH}_{2}\right)_{n} \mathrm{PR}^{\prime \prime}{ }_{2}\right)_{2}\right]^{+}$exhibit potent cytotoxicity towards cancer cells in vitro, 1,2 in addition, they show antifungal and modest antibacterial properties. ${ }^{2}$ However, none of these has reached clinical trials because of extreme mitochondrial toxicity related to uncoupling of oxidative phosphorylation for the gold(I) analogues. ${ }^{3}$ We now report that the $\mathrm{Ag}(\mathrm{I})$ complex, $\left[\mathrm{Ag}\left(\mathrm{Et}_{2} \mathrm{PCH}_{2} \mathrm{CH}_{2} \mathrm{PPh}_{2}\right)_{2}\right] \mathrm{NO}_{3}$, (I), inhibits the growth of yeast selectively in non-fermentable media, indicating a primary effect on mitochondrial function. Yeast cells in a fermentable medium (containing glucose) show a high frequency of the mitochondrial mutation petite, while toxicity (measured as cell death) is low. Aspirin in the growth medium largely reverses the antimitochondrial effects of the complex. The chemistry of this complex and the implications for drug design will be discussed.

We thank the Association for International Cancer Research, EC HCM programme, Royal Society and ULIRS for their support of this work.

\section{References}

1. S.J. Berners-Price, G.R. Girard, D.T. Hill, B.M. Sutton, P.S. Jarrett, L.F. Faucette, R.K. Johnson, C.K. Mirabelli and P.J. Sadler, J. Med. Chem., 1990, 33, 1386-1392.

2. S.J. Bemers-Price, R.K. Johnson, A.J. Giovenella, L.F. Faucette, C.K. Mirabelli and P.J. Sadler, J. Inorg. Biochem., 1988, 33, 285-295.

3, G.D. Hoke, G.F. Rush, G.E. Bossard, J.V. McArdle, B.D. Jensen and C.K. Mirabelli, J. Biol. Chem., 1988, 263, 11203. 